\title{
Gandhara Art's Influence on Buddhist Art in Xinjiang, China
}

\author{
Wenqi He \\ International Department of Wuhan No.6 High school, Wuhan, China
}

\begin{abstract}
The Gandhara region of India was the origin of Buddhist art, and, due to its unique geographical location, it was a place where European and Asian civilizations mingled. The original Gandhara Buddhist art style was largely influenced by the style of Classical Greek sculpture. With the gradual development, its sculpture art and Buddhist stories entered a prosperous period and began to spread eastward, exerting a profound impact on the development of Buddhist art in the early stage of western Regions and later in Xinjiang.
\end{abstract}

Keywords: Gandhara; Xinjiang; Buddhist Art.

\section{Introduction}

The emergence and subsequent development of Buddha statues are largely influenced by foreign cultures and regions. "Before the creation of the Buddha, according to Hinayana Buddhism, the Buddha was a saint of the super-ordinary people, the supreme, and the image of the Buddha could not be described by words and pictures of time."[1]

Different from Hinayana Buddhism, Mahayana Buddhism aims to "save all living beings", helping believers to intervene after obtaining self-liberation so that all living beings can become Buddhas. Hinayana Buddhism and Mahayana Buddhism developed independently in India and spread to different regions.

Gandhara was located in northern India, which was frequently involved in wars between different countries due to its special geographical location. Liu Bo wrote in The Origin of Buddha Statues, "Gandhara, first as one of the sixteen states of ancient India, was conquered by the Persian Empire in the sixth century BC. Conquered by Alexander the Great of Macedonia in 326 BC, it was recaptured by the Maurya in $305 \mathrm{BC}$ and began to spread Buddhism. In $190 \mathrm{BC}$ it was conquered by the Bactria Greeks, and since then it has never ceased to be contested [2]. The war-torn gandhara region became a place where ancient civilizations met and merged." In Gandhara during the Kushan dynasty, a vibrant culture mingled with the liberal ideas of ancient Greece. The cultural input of "anthropomorphism" sculpture makes Buddhists crave the image of Buddha, and the taboo of "Buddha should not be made" is broken under multiple factors. "The central Philosophy of Greece has an unshakable belief in the affirmation of human value, the affirmation and pursuit of all the richness and needs of human life. So the basic spirit of Greek sculpture is to celebrate man as the most important creation in the universe." (The artistic style of Buddhist sculpture in Han Dynasty) In Gandhara, with the introduction of Greek art and culture, Gandhara Buddha statues is provided with a distinct style characteristic of Greek classicism: solemn manner. Chiwalf once said, "The artists of Gandhara followed the example of Greece in the steps of reform." [3] Some scholars believe that the subsequent writing of a large number of stories about Buddha, from Buddha's birth, Buddha's dissemination of the dharma, to Buddha's nirvana, was influenced by Greek mythology. In The Art of Buddhism, Annissac says, "The Buddha... was represented an Apollo, followed loyally by Brahma and Indra, the Hindu running gods, who are represented as Zeus and Achilles."[4] It can be seen that the input of Greek culture had a profound influence on the development of Gandhara Buddhism. Later, this paper will prove the influence of Greek culture on Gandhara Buddhism at the artistic level (Buddha image) by comparing the similarities and differences between the two cultures. 


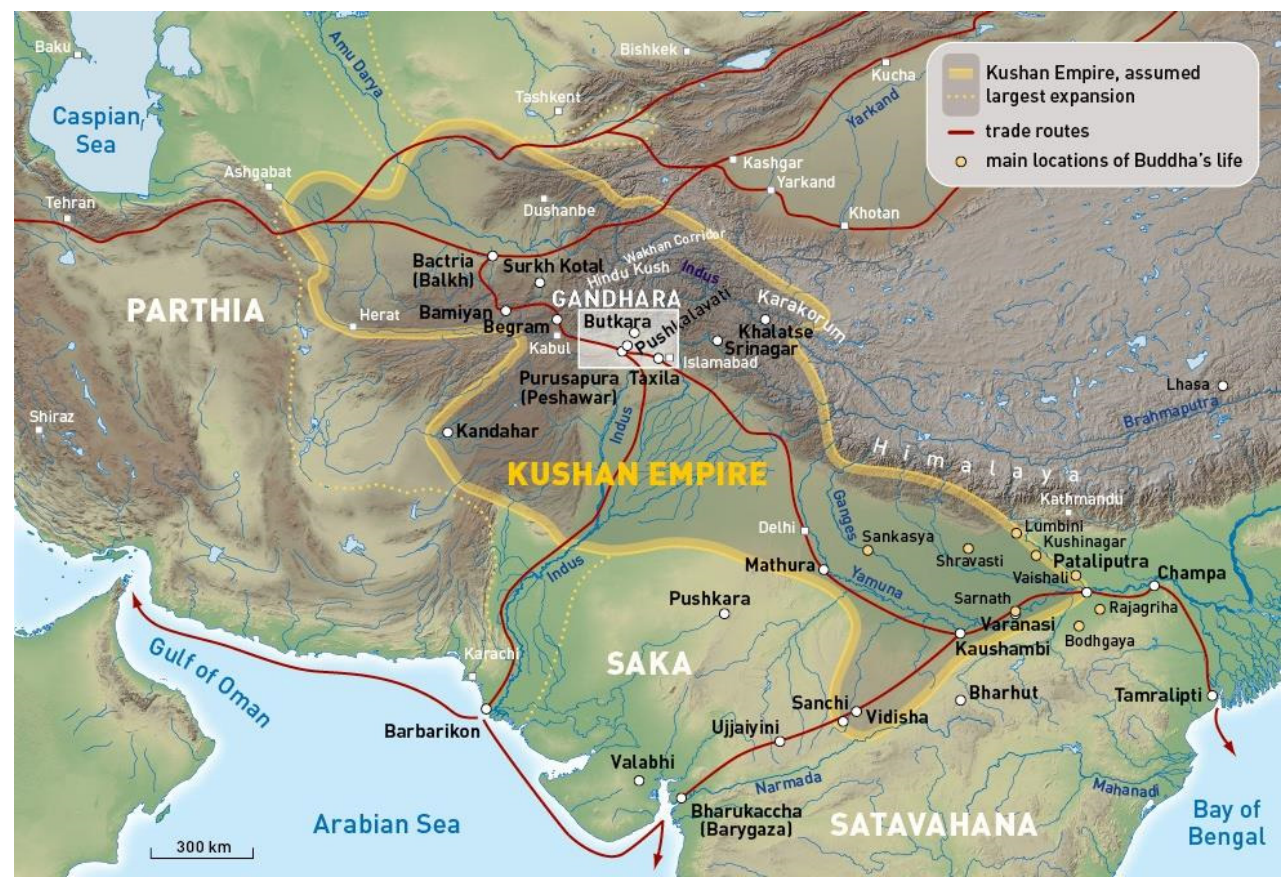

Figure 1. Distribution map of Buddhist sites

\section{The Origin of Gandhara Buddhist Art}

In the sixth century BC, Gandhara already existed in the South Asian subcontinent, one of the sixteen great states in the age of nations. It was recorded in the Book of Han in the Western Han Dynasty that "At first, after being defeated by the Hun, Yuezhi moved to Daxia, dividing the state into Xiumi, Shuangmi, Kushan, Taitun and Dumi, a total of five Linghous. More than a hundred years later, Qiu Jiuque, the Linghou of Kushan killed four other Linghous and made himself the King under the title of Kushan. The King of Kushan invaded Anxi, occupied Gaofu area, and destroyed Puda and Chubin, eventually occupying their entire territory. Qiu Jiuque died in his eighties and was succeeded to the throne by his son Yan Gaozhen who later destroyed Tianzhu and set a general in charge of Tianzhu. From then on, Yuezhi became the most prosperous and powerful state, and other states called it Kushan Empire."[5]

Gandhara is located in the Hindu Kush mountains, where the people mainly live in the valley formed by the Kabul, Swat and Indus rivers. Gandhara's geographical location, at the junction of Eurasia and as the birthplace of Indian civilization, provided an important stage for the development of world civilization. The history of Gandhara began in the 6th to 5th centuries BC: Medo-Persian empire; 4th century BC: Hellenistic period; 3rd century BC: Mauryan Dynasty; 2nd century BC: Greek kingdom of the great Xia; 1st century BC: Scythian kingdom in India; 1st century AD: The Kingdom of Patea in India; 1st - 2nd centuries AD: Kushan Dynasty; 3rd century AD: Sassanian Dynasty; 4th - 5th centuries AD: Duroguigan; and 5th - 6th centuries: The White Huns.

In the early stage of the development of Indian Buddhism, Buddha was not made into a statue, and its predecessor was Buddha Dharma, bodhi tree, Buddha footprint and other symbols. In ancient India, carved Buddhas were considered sacrilegious.

In the 2nd century BC, Indian Buddhism started a new movement, experiencing the first and second gatherings. Sectarian Buddhism, which centered on the monks, was engaged in and a new movement of Buddhism arose from believers in the home. As the movement grew during the Asoka period, new Sutras were compiled by devotees. Buddhists who follow the new and more specialized view call themselves Mahayana while the old Buddhists view themselves Hinayana (PrajnaparamitaSutra, Saddharmapundarika Sutra, Huayan Sutra and Pure Land Sutra).[6] During the subsequent Kushan dynasty in India, Mahayana Buddhism gradually emerged in India. In Indian Buddhism, the Mahayana Buddhism, which focuses on the universal compassion of all living beings, gradually 
occupied the dominant position of Indian Buddhism, so that the Buddha became a divine savior. At the same time, in Gandhara, Mahayana Buddhism's ideas coincided with the Greek philosophy of life in continental Europe, with the affirmation of human values at its core. Buddha statues were also formed with the traditional cultural input of "god and man" in Greece and Rome. Craftsmen in Gandhara, India, broke the Buddhist precepts one after another to seek to create the image of Buddha. [7].

Kushan craftsmen modeled the image of the Buddha in reference to the statues of Greek deities. The early Gandhara Buddha statues were dressed in Greek leather robes and looked solemn, showing a distinct style characteristic of Greek classicism. [8] John Marshal divided Gandhara art into four main periods: (AD 50-150) archaic period, (AD 2nd-3rd centuries) peak, (AD 3rd century) decline, and (AD 4th-5th century) the prevalence of stucco statues. At the beginning of the Greek elements in Gandhara, the characteristics of Indian art were still very distinct. Later, at the peak of its development, Greek art became more and more influential in Gandhara Buddhist art. [9]

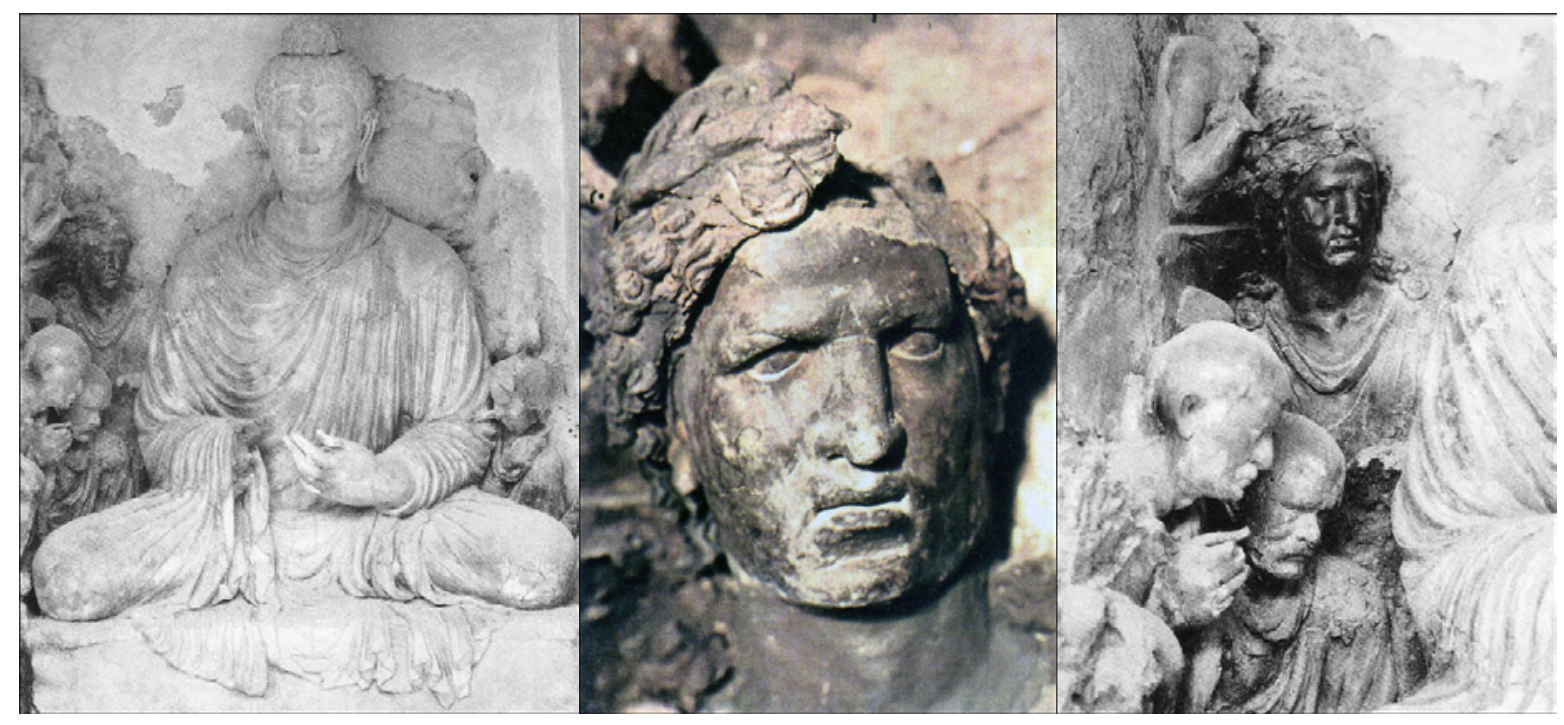

Figure 2. Early Gandhara Buddha Statues [10]

\section{Gandhara Buddhist Art from the East to the West}

During the reign of the Kushan dynasty, the worship of Buddha statues gradually increased in various regions. With Gandhara and Mathura as the two centers, the influence of Buddha sculpture art gradually expanded. When King Kushan promoted Buddhism in the territory, eminent monks began to spread Buddhism, and Buddhist views were widely respected in the process of spreading. During this period, from south of the Amu darya in the west to the Syr River valley in the north, as well as Tocharostan and transoxiana (in what is now Afghanistan, Uzbekistan, Kyrgyzstan and so on), Buddhism was greatly respected and respected by the rulers. [11] Around A.D., Buddhism in the above areas already occupied an important position. These two regions were important trading nodes on the ancient Silk Road.

Around A.D., there were three main routes for Buddhism to spread from Gandhara in ancient India to the Western Regions:

(1) Southern section of ancient Silk Road. Starting from Taxila in Gandhara, it passed through Lanshi City in Great Summer and crossed the Pamirs Plateau to Shul

(2) Starting from Swat in Gandhara, it crossed Hindu Kush Mountains in the north, then the Amu Darya (Wuhu River), and the Pamirs Plateau in the east, and reached Shul from the Hongqi Lapu Mountain

(3) From Gandhara, it traveled east through Kashmir and crossed over Har goolun Range to Yutian [12] 
The formation of Kashmir, written in 958-966, contains a map of the route from Yutian to Kashmir, much like today's guidebooks. The book also testifies to the frequent exchanges between the two regions of Yutian and Kashmir. In the eastward spread of Buddhism, from Gandhara to Central Asia and then to western China, early Chinese Buddhism was most influenced by Central Asian Buddhism. With the process of missionary work, Buddhism in Central Asia had some localized changes in order to adapt to local conditions. Therefore, early Chinese Buddhist art was not directly influenced by Indian Buddhism.

Since the Kushan period, Buddhism began to spread to China. In the 5 th century AD, the Yanyanda people invaded Gandhara and enforced a policy of persecution of Buddhism, which caused the decline of Buddhism in Gandhara and Central Asia at that time. Therefore, Buddhism in the Western Regions developed for a long time and gradually became the center of Buddhism. [13]

The Silk Road in the western regions of China (Xinjiang), is divided into the north and south due to special geographical factors. Based on the description of the Silk Road in the Book of Han: Biography of the Western Regions, there are two ways out of Western Regions from Yumen Guan and Yangguan. [14]

Buddhist sites in Xinjiang are mainly located in the northern and southern routes of the Silk Road, namely the northern and southern margins of the Tarim Basin, with a total of six districts: Yutian district, Shule district, Shanshan district, Qiuci district, Yanqi district and Gaochang District. Gandhara art style has a great influence on Buddha sculpture and architectural ornaments and relief art in the six districts, which is clearly reflected in the existing sites.

\section{The Impact on the Western Regions}

After the eastward spread of Buddhism from Gandhara to the Western Regions, the early Buddhist art style in Xinjiang was greatly influenced by Gandhara, as can be seen in the sculptural details in early Xinjiang architectural ornaments and sculptures. Due to the different geographical locations of Xinjiang in China and Gandhara, the available sculptural materials are different. Buddhist sculptures in Xinjiang can be divided into wood carving, clay carving, metal carving, stone carving and pottery carving. According to the subject matter of their sculptures and paintings: the first is purely GrecoRoman subject matter and style; the second is clay model and clay image; and the third is Gandhara Buddha.[15]

\subsection{Building Decorations}

Buddhist architectural ornaments with Gandhara elements, statues of Greek mythological figures, and Gandharan-style patterns from early Xinjiang in China have been unearthed from sites of Yotegan, Ravak, and Nyya of Yutian, Milan in Loulan, and Seven Stars in Yanqi.

The wooden crossbeam unearthed at L.B.I Buddhist Temple in Loulan site consists of four wooden beams. The side L.B.II.05 is a relief plate of rose, beneath which hang clusters of circles, each with an eight-petaled lotus. The side of 1.B.II.0027, with its relief of figures and arcades, is so badly damaged that only faint carving marks of eight Buddhas can be seen. The side of L.B.II.0037 (as shown in Figure. 3) shows the embossed pattern of a continuous scroll. Two root-like lines run from the middle to the sides of the beam in the same way, and each root-like line has three trivalved leaves in a symmetrical shape. In the middle of the beam, there is a six-petal rose flower, and the lower part of the beam is embossed with a diamond pattern.

\subsection{Gandhara Buddhist Sculptures}

There are many Gandhara sculptures, mostly stucco statues and clay models, along the northern and southern routes of the Silk Road in Xinjiang. Stucco statues were widely used in Taxila from the end of the 1st century AD to the middle of the 5th century AD. Such stucco statues spread to Xinjiang with the eastward spread of Gandhara Buddhist art, influencing sculpture and plastic arts in Xinjiang. Many Gandhara Buddha sculptures from Xinjiang have been unearthed in Dandan Wulik, Andil, 
Rewake, Tumushuke, Milan and Loulan. According to the forms of expression of unearthed sculptures, Gandhara Buddhist sculptures in Xinjiang can be divided into relief stories and Buddha carving. Relief stories are mainly about Buddhism. Buddhist sculpture is mainly composed of single Buddha statues or rows of Buddha statues on the wall.[16]

A relief sculpture of Bodhisattva No. D.i.10 (as shown in Figure 4), about 5 inches high, was unearthed at D.I.I Buddhist Temple in Dandan Wulike site. It is an image of a seated Bodhisattva. In the statue, a Bodhisattva is seated in a lotus throne. From the details of the carving, it can be seen that the Bodhisattva's head is illuminated and backlit, so it must be the bun, but the facial expression is blurred. The Bodhisattva's left hand is placed on the same knee, and the right hand shows the gesture of abhaya mudra. He wears a shouldered garment, and the wrinkles of the garment are clearly visible. Its shoulder-style clothes have a distinct Gandhara art style.

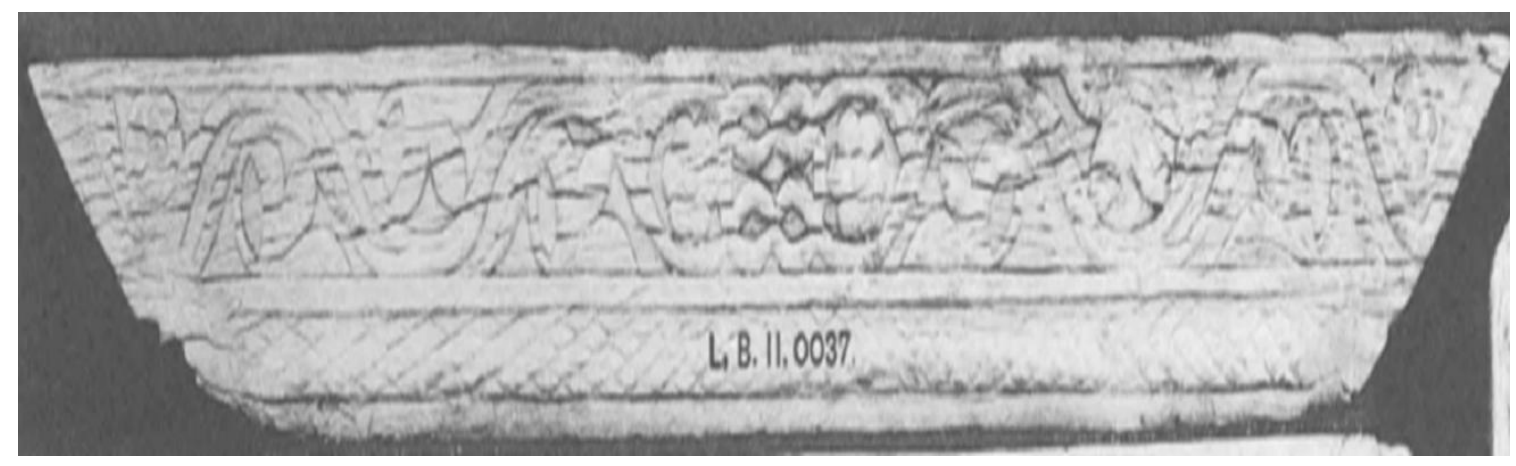

Figure 3. The wooden crossbeam[17]

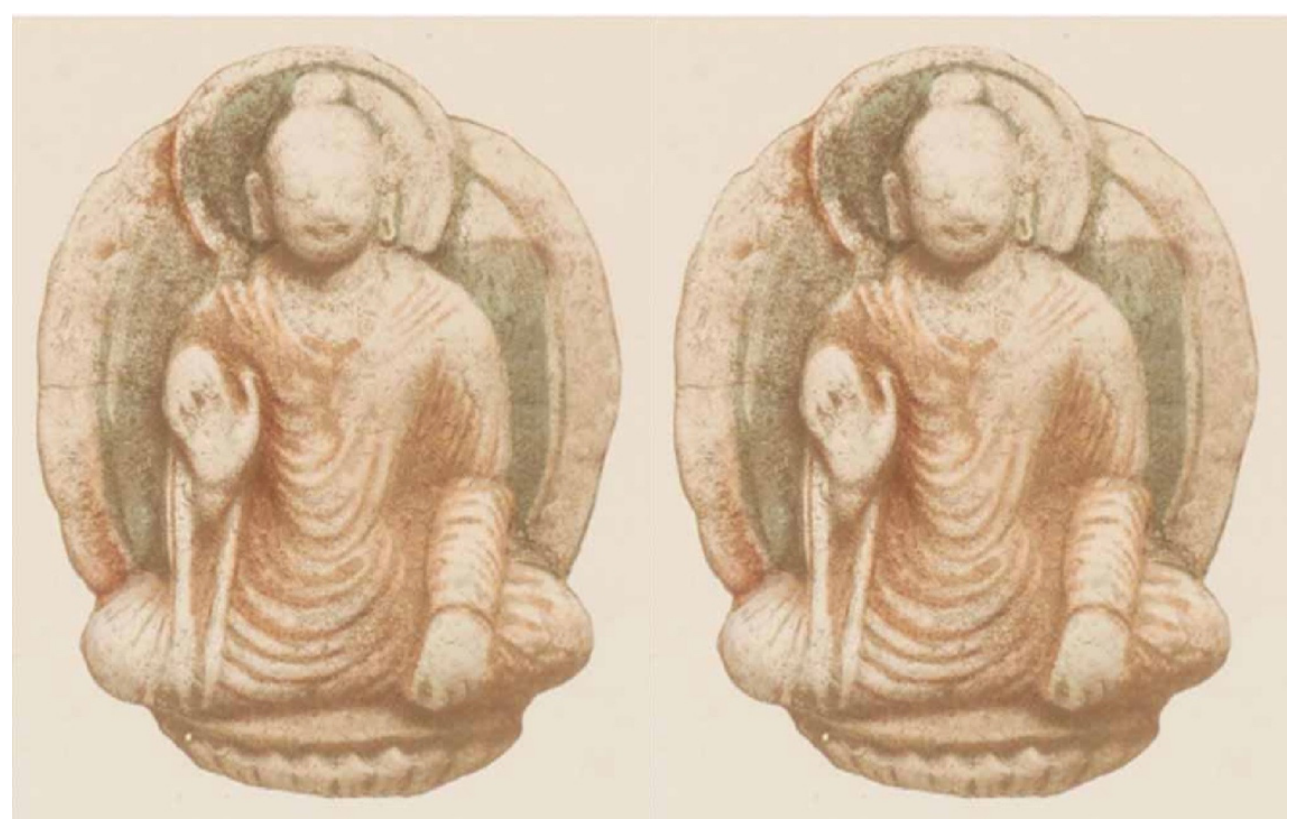

Figure 4. Relief of Bodhisattva [18]

\subsection{Cliff Painting}

Buddhist art in Gandhara developed its own symbols, architectural motifs, characters and story settings. Numerous themes and images in the stories of Buddha and Jatakas in previous lives explain the profound influence of Gandhara Buddhism on Xinjiang.

As can be seen from the relics unearthed in the eastern route, Buddhist images are closely associated with the original image of Buddha in Gandhara. When Buddhism spread east from Gandhara to Xinjiang, the Kashmir Valley and the western Himalayas were the corridors connecting 
the first two regions. Images found among them reveal the development of Buddhist art from India to China along the ancient Silk Road.[19]

Bunsen stories are painted on rocks in the Kashmir Valley and the western Himalayas, as a crossing point from Gandhara to Xinjiang. Bunsen stories of Buddhist literature and art were transplanted and painted here in an attempt to further link Buddhism here with Buddhism in the distant Ganges region and to better spread it.[20]

The story of the Buddha in Kezier echelon Grotto (Grotto 110) adopts gandhara narrative mode. A. [21] Santoro argues that the kizier frescoes, despite their obvious connection to the Gandhara models, are not simply reproductions of the original.

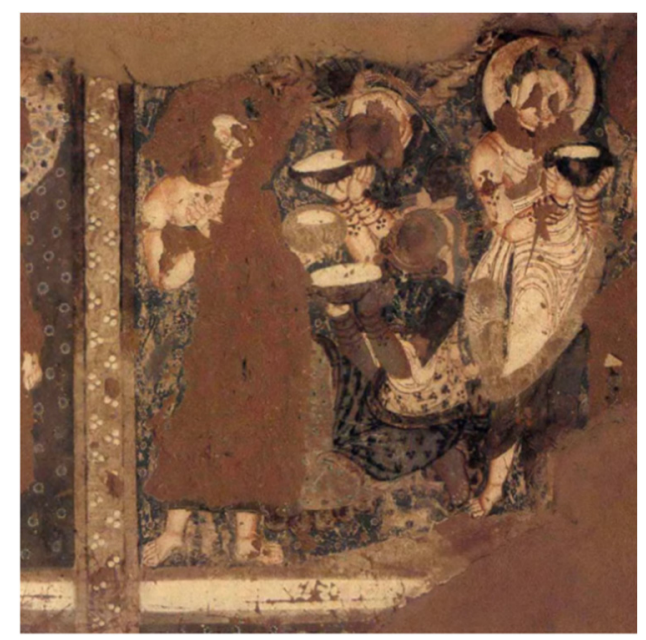

Figure 5. Grotto 110 of Kezier echelon Grotto West Side, Figure of Buddha preaching, The herdswoman served the minced meatfigure

\section{Conclusion}

In the view of early Indian Buddhism, the Buddha was a saint of super-ordinary people, so the principle of "Buddha image should not be done" was always adhered to. The image of Buddha is replaced by an inhuman image like bodhi. Until the Kushan Dynasty, with the rise of Mahayana Buddhism and the promotion of the concept of "saving all living beings", the input of the ancient Greek "anthropomorphism" statue culture in Gandhara, India broke the centuries of taboo that the image of Buddha should not be made. In the early stage of the development of Buddha sculpture art, influenced by Greek culture, the early Gandhara statues all wore Greek leather robes and looked solemn. As time went by, the development of Gandhara Buddha art gradually reached its heyday and began to spread eastward along the Silk Road, exerting a profound influence on the culture of the eastern region. With the spread of Buddhism from the east to the west, the early Buddhist art style in Xinjiang embodies a distinctive Gandhara art style. The architectural ornaments, Buddhist sculptures and rock paintings from the Kushan period unearthed in Xinjiang share many common patterns and structures with those from Gandhara. Rocks in the Kashmir Valley and the western Himalayas, where Buddhism has spread from east to west, depict Bunsen stories of Buddhas from Gandhara. However, with its continued development in Xinjiang, Buddhist art has been gradually injected into the local cultural characteristics, making localized changes in the original Gandhara Buddhist art. During the spread of Buddhist art from Gandhara to Xinjiang, in order to adapt to the influence of local culture, western Buddhist art and Gandhara Buddhist art were differentiated. Based on this conclusion, when Buddhist art spread eastward from Gandhara, it was influenced by the cultures along the way and localized to some extent. Thus, the further away the gandhara region is, the less influenced by Gendra art. 


\section{References}

[1] Xu Jing. Research on Artistic Style of Buddha Sculpture in Han Dynasty [D]. Nanjing University, 2013.

[2] Liu Bo. Origin of Buddha [J]. Chinese Children, 2015(8):96-96.

[3] Zwalf W. The shrines of Gandhara[J]. 1979.

[4] Manuscripts B \&. [BUDDHIST ART]. -- ANESAKI, M. Buddhist [J].

[5] [Western Han Dynasty] Ban Gu, [Tang] Yan Shigu Note: Han Shu, Beijing: Zhonghua Book Company, 1964.

[6] Warder, A. K, Wang Shian. History of Indian Buddhism[J]. 1987.pg.74.

[7] Same as endnote ii.

[8] Zhu Yingrong, Qiuci Culture and Gandhara Culture.[J].Journal of Xinjiang University (Philosophy, Humanities \& Social Sciences), 1988(01):15-25.

[9] The Buddhist art of Gandhara: [M]. Oriental Books Reprint Corporation, 1980.

[10] Figure 7. The First Sermon, Vajrapāni-Alexander, Tapa-e Shotor, Niche V3, Clay (1.20 x 1.30 m). (Photos: Z. Tarzi, personal photographic archive; after Tarzi 1991, unnumbered fig.; Tarzi, personal photographic archive.).

[11] Jia Yingyi, Qi Xiaoshan. Buddhism Spreading to China[M]. Shanghai Ancient Books Publishing House, 2006, p. 3.

[12] Man ying-ying. research on Gandhara art and its eastward spread to qiuci [J]. Journal of Northwest Minzu University (Philosophy and Social Sciences), 2013(03):178-181.

[13] Zou Fei. On the influence of Gandhara culture on China's Western Regions [D]. Lanzhou University, 2019.

[14] [Western Han Dynasty] Ban Gu, [Tang] Yan Shigu Note: Han Shu, Beijing: Zhonghua Book Company, 1964:3872.

[15] Shen Fuwei. History of Cultural Exchange between China and the West [M]. Shanghai People's Publishing House, 2006:101-105.

[16] Same as endnote xiii.137.

[17] Aurel Stein, Ancient Khotan, Plate LIV.

[18] Same as endnote xvii.

[19] Sailina Aoqiluo, Zheng Yanyan. Buddhist rock paintings in the upper reaches of the Indus River and their relationship with ancient Buddhist art in Xinjiang [J]. The Western Regions Studies .2021 (01): 114-128.

[20] Neelis.2014. p.58. note 36.

[21] A. Santoro. "Gandhara and Kizil: The Buddist's Life in the Stairs Cave". Rivista degli Studi Orientali. Voli. 77. Fasc. 1/4. 2003.pp.115-133. 